\title{
Geoheritage: the Foundation for Sustainable Geotourism
}

\section{Mario Bentivenga ${ }^{1} \cdot$ Francesco Cavalcante $^{2} \cdot$ Giuseppe Mastronuzzi $^{3} \cdot$ Giuseppe Palladino $^{4} \cdot$ Giacomo Prosser $^{1}$}

Published online: 6December 2019

(C) The European Association for Conservation of the Geological Heritage 2019

\section{Introduction}

Over recent decades, many studies on geological heritage have been carried out, one of the main results being the dissemination of a more enthusiastic approach to the information on geological processes that can be deduced from outcrops and landscapes (Reynard \& Brilha 2018). Many events, organized in different locations across the world by scientific associations, societies and research institutions have contributed to encourage people's interest in studying the processes that affect the Earth's surface. Numerous scientific papers have addressed issues concerning geological heritage, notably the census and the study of geosites, places where geological peculiarities can be observed, which constitutes the first step towards the application of all strategies useful for geoconservation and enhancement of this inexhaustible natural resource (Wimbledon 2011). Geosites can allow the natural phenomena that occur on the Earth's surface to be highlighted and facilitate their understanding (Cook and Abbott 2015). Studies of geosites have also served to raise awareness among the administrators of particular areas and make it clear that the time had come to plan actions aimed at geoconservation and compatible enhancement of the geological heritage (Bentivenga et al. 2015 and Palladino et al. 2013). Moreover, such studies also serve to increase general awareness

This article is part of the Topical Collection on Geoheritage: the foundation for sustainable geotourism

Mario Bentivenga

mario.bentivenga@unibas.it

1 Department of Science, University of Basilicata, Via dell'Ateneo Lucano, 10, 85100 Potenza, Italy

2 Institute of Methodologies for Environmental Analysis (IMAA), Italian Research Council (CNR), Contrada Santa Loya, Tito, 85050 Potenza, Italy

3 Department of Earth Environmental Sciences, University of Bari, Via Orabona, 4, 70125 Bari, Italy

4 Geology and Petroleum Geology, University of Aberdeen, Aberdeen, UK of the geological heritage among local and national communities. Furthermore, study of geosites has facilitated the process of developing laws on the subject and creating databases useful for the preservation and a better knowledge of geological heritage as well as for territorial planning (Geremia et al. 2015).

The purpose of this Geoheritage special issue is to reinforce the idea that a rigorous study of geosites is fundamental for dissemination of knowledge on geological processes in connection with geotourism. Furthermore, special emphasis is given to geoconservation and to the new approaches that must be applied for protecting the geological heritage (Henriques et al. 2011; Gray 2018). The basic study and the securing of geosites must follow a careful study that leads to their evaluation, while respecting their original features, in order to inform the development of sustainable tourism. Geotourism is a form of tourism that allows the discovery of the geological peculiarities of the visited territories, combined with other natural and human resources. This tourism follows the principles of the "European Landscape Convention," and consequently, people can benefit from the sustainable use of their natural resources and at the same time are able to reinvest in the management and protection of geodiversity. Geotourism can be considered to be one of the tools that allows a better knowledge and development of a territory, based on the principles of environmental sustainability, which all land managers should follow. It has now been established that scientific studies not only improve education but also provide useful information for managers of the territory and, more generally, to people working in the area. Moreover, investing in studies aimed at geoconservation and enhancing the geological heritage for sustainable tourism could generate new job opportunities connected to geotourism. When associated with other touristic attractors, the presence of suitable geosites can significantly increase the number of visitors to an area.

This special issue of Geoheritage Journal collects together 23 papers presented at the conference 'Geoheritage: the foundation for sustainable geotourism' held in Sasso di Castalda, Potenza (Italy), on 26 and 27 April 2018, organized by University of Basilicata, SIGEA, and academic spin-off group EXTRAGEO. The presented papers focus on current methods of research on 
geosites and discuss topics related to geodiversity and geoheritage. In addition, some papers illustrate examples of geoconservation and valorization of the geological heritage designed to enhance sustainable tourism. The papers published in the special issue can be grouped into five general topics that are described below:

The first topic comprises papers focusing on scientific studies of geoheritage. Examples of geosites occurring in different geological and geomorphological contexts are included, for instance, geosites occurring in a volcanic area of Sardinia (Gioncada et al., 2019), underground geosites connected to caves in Mesozoic limestones of Southern Italy (Liso et al., 2019), and a geosite located within a peculiar Pleistocene sandstone of the Southern Apennines that preserves caves connected to human activity (Bentivenga et al., 2019). Other papers are related to the study of geological itineraries including different geosites, such as the Agri Valley in Southern Italy (Bucci et al., 2019), where an itinerary connecting a series of significant outcrops which illustrate the tectonic evolution of the Southern Apennines. Megerssa et al., 2019 describe some potential geosites in a volcanic environment which, together with numerous other sites showing cultural and historical interest, can lead to the establishment of the first Geopark in Ethiopia. Another paper, describing the Peshawar basin in Pakistan, highlights the need to plan geoconservation activities for geosites of international interest that are under threat of destruction (Yaseen et al., 2019). In the Matera area, Bonomo et al., 2019 describe old quarries in limestones, of great geological interest, that should be safeguarded and enhanced. The paper of Brandolini and Pelfini, 2019 describes the floodplain of the Po River (Italy), affected by human settlements and discuss why archaeomorphological and geomorphological investigations have been considered to understand how man has influenced natural geomorphological processes.

In addition, Sardella et al., 2019 propose an innovative method to document and protect the "Grotta Romanelli" which is in a state of degradation.

The second topic includes articles that consider the relationship between geoheritage and landscape, with particular emphasis on the description of the processes that generate different landscapes. Specifically, Tognaccini, 2019 and Filocamo et al., 2019 propose geosites and geological itineraries as tools for a better understanding of the landscape in order to generate respect for it and to generate sustainable tourism over time.

The third topic includes articles that consider the Geoheritage and territorial planning. The presented articles illustrate good practices to follow for territorial planning in areas characterized by high geodiversity, as described by Muntoni et al., 2019, Saganeiti et al., 2019, and Pilogallo et al., 2019. The first paper deal with the planning of the territory of the mining park of Sardinia. In the second work, a multidisciplinary approach able to evaluate the correlation between landslides and spatial distribution of urban areas is proposed, while the third paper discusses the sustainable governance of a territory through planning activities based on the integration of ecological, economic, and socio-political elements within an interdisciplinary framework that includes the evaluation of the ecosystem. The article by Gizzi et al., 2019 proposes an integrated methodological approach to the analysis of natural and anthropic factors that cause the abandonment of settlements and their current conservation state, following a geomorphological, historical, and remote sensing approach. The work provides suggestions on the best strategies to adopt in order to geoconserve and promote abandoned villages such as Craco (Basilicata, Southern Italy) (Bentivenga et al. 2005). The works by Del Luca et al., 2019 and Lezzerini et al., 2019, respectively, highlight the mechanical characteristics of typical building stones from Southern Italy (Pietra di Gorgoglione) to help understand their most appropriate use, and describe the different rocks used for the construction of some monuments in Pisa. The paper of Margiotta and Parise, 2019 deals with problems related to the hydraulic and geomorphological risks in the wetlands of the eastern coast of Salento (Southern Italy) and promotes their great environmental value.

The fourth topic includes articles about techniques for the enhancement of Geoheritage. The study by Marrosu and Balvis, 2019 assesses the environmental impact in areas of geological and naturalistic interest in which climbing activities are carried out, in order to develop a more sustainable tourism. The work by Pescatore et al., 2019 presents a proposal for multicultural and multilevel management of composite geomorphosites. Rizzo et al., 2019 present a case study on the enhancement of volcanic geosites in the Geological Mining Historical and Environmental Park of Sardinia. The aim of this latter work is to develop a tool for promoting the geological culture and the related geotourism.

The fifth topic includes papers on sustainable geotourism, which highlight problems connected with the management of geological heritage. In particular, Shekhar et al., 2019 studied the area of Western Kutch in India in order to make the local population aware of the importance of the geological heritage of the area, which can be included in a geopark. The paper of Sánchez Rivero et al., 2019 deals with the identification of the geotouristic profile of a Geopark in Spain using a binary login modeling capable of understanding its geotouristic potential.

\section{References}

Bentivenga M, Foresi LM, Prestera A, Prosser G, Sabia M (2005) Structures located at the front of a thrust and fold belt: the Craco area (Southern Apennines, Italy). Boll Soc Geol It 124(2):367-376

Bentivenga M, Palladino G, Prosser G, Guglielmi P, Geremia F, Laviano A (2015) A geological itinerary through the southern Apennine Thrust Belt (Basilicata-Southern Italy). Geoheritage J 9:1-17. https://doi.org/10.1007/s12371-015-0168-6

Cook T, Abbott L (2015) Geoheritage: preserving the earth's legacy: EARTH https://www.earthmagazine.org/article/ geoheritagepreserving-earths-legacy 
Geremia F, Bentivenga M, Palladino G (2015) Environmental geology applied to geoconservation in the interaction between geosites and linear infrastructures in south-eastern Italy. Geoheritage J. 7:33-46. https://doi.org/10.1007/s12371-015-0145-0

Gray M (2018) Geodiversity: the backbone of geoheritage and geoconservation. In: Reynard E, Brilha J (eds) Geoheritage: assessment, protection, and management. Elsevier, Amsterdam, pp 13-25

Henriques MH, Pena Dos Reis R, Brilha J, Mota T (2011) Geoconservation as an emerging geoscience. Geoheritage J. 3: $117-128$

Palladino G, Prosser G, Bentivenga M (2013) The geological itinerary of Sasso di Castalda: a journey into the geological history of the Southern Apennine thrust-belt (Basilicata-Southern Italy). Geoheritage J. 5:47-58. https://doi.org/10.1007/s12371-012-0073-1

Reynard E, Brilha J (2018) Geoheritage: a multidisciplinary and applied research topic. In: Reynard E, Brilha J (eds) Geoheritage: assessment, protection, and management. Elsevier, Amsterdam, pp 433438

Wimbledon WAP (2011) Geosites - a mechanism for protection, integrating national and international of heritage sites. In: Bentivenga $\mathrm{M}$ (ed) Il patrimonio geologico: una risorsa da proteggere e valorizzare. Atti Conv. Naz. SIGEA, 29-30 aprile 2010, Sasso di Castalda, PZ, Geologia dell'Ambiente, Suppl n 2, 13-25

\section{In this Special Issue}

Bentivenga M, Capece A, Guglielmi P, Martorano S, Napoleone D, Palladino G, De Luca V (2019) The San Giorgio Lucano cave complex (Basilicata, Southern Italy): a geosite to protect and enhance. https://doi.org/10.1007/s12371-019-00374-1. Geoheritage this volume

Bonomo AE, Acito AM, Prosser G, Rizzo G, Munnecke A, Koch R, Bentivenga M. (2019) Matera old quarries: geological and historical archive to be protected and valorized. Geoheritage this volume

Brandolini F, Cremaschi M, Pelfini M (2019) Estimating the potential of archaeo-historical data in the definition of geomorphosites and geoeducational itineraries in the Central Po Plain (N Italy). Geoheritage this volume

Bucci F, Tavarnelli E, Novellino R, Palladino G, Guglielmi P, Laurita S, Prosser G, Bentivenga M (2019) The history of the southern Apennines of Italy preserved in the geosites along a geological itinerary in the high agri valley. Geoheritage this volume

De Luca V, Bentivenga M, Cavalcante F, Lezzerini M, Marano C, Palladino G. \& Prosser G. (2019) Geological features, physical and mechanical properties of the Gorgoglione building stone of Basilicata (Southern Italy). DOI: https://doi.org/10.1007/s12371019-00412-y. Geoheritage this volume

Filocamo F, Rosskopf CM, Amato V (2019) A contribution to the understanding of the Apennine landscapes: the potential role of Molise geosites. Geoheritage this volume

Gioncada A, Pitzalis E, Cioni R, Fulignati P, Lezzerini M, Mundula F, Funedda A (2019) The volcanic and mining geoheritage of San Pietro Island (Sulcis, Sardinia, Italy): the potential for geosite valorization https://doi.org/10.1007/s12371-019-00385-y. Geoheritage this volume

Gizzi FT, Bentivenga M, Lasaponara R, Danese M, Potenza MR, Sileo M, Masini N (2019) Natural hazards, human factors, and "ghost towns": a multi-level approach. https://doi.org/10.1007/s12371019-00377-y. Geoheritage this volume
Lezzerini M, Pagnotta S, Legnaioli S, Palleschi V (2019) Walking in the streets of Pisa to discover the stones used in the Middle Ages. Geoheritage this volume

Liso IS, Chieco M, Fiore A, Pisano L, Parise M (2019) Underground geosites and caving speleotourism: some considerations, from a case study in southern Italy. Geoheritage this volume

Margiotta S, Parise M (2019) Hydraulic and geomorphological hazards at wetland geosites along the eastern coast of Salento (SE Italy). Geoheritage this volume

Marrosu GM Balvis T (2019) Environmental impact assessment in climbing activities, a new method to develop a sustainable tourism in geological and nature reserves. Geoheritage this volume

Megerssa L, Rapprich V, Novotný R, Verner K, Erban V, Legesse F, Abera M (2019) Inventory of key geo-sites in the Butajira volcanic field: perspective for the first geopark in Ethiopia. Geoheritage this volume

Muntoni F, Balvis T, Rizzo R, Loru P (2019) Territorial planning of geological mining historical and environmental park of Sardinia. Geoheritage this volume

Pescatore E, Bentivenga M Giano SI, Siervo V. (2019) Geomorphosites: versatile tools in geoheritage cultural dissemination. https://doi.org/ 10.1007/s12371-019-00378-x. Geoheritage this volume

Pilogallo A Nolè G, Amato F, Saganeiti L, Bentivenga M, Palladino G, Scorza F, Murgante B Las CG (2019) Geotourism as a specialization in the territorial context of the Basilicata Region (Southern Italy). https://doi.org/10.1007/s12371-019-00396-9. Geoheritage this volume

Rizzo R., Sernagiotto S., Balvis T., Muntoni F. (2019) Promotion and enhancement of the volcanic geosites of the geological mining historical and environmental park of Sardinia: the case of the Monte Arci volcanic complex (Central-Western Sardinia). Geoheritage this volume

Saganeiti L, Bentivenga M, Pilogallo A, Scorza F, Nolè G, Tucci B, Palladino G, Murgante B (2019) The shape of settlement fabric and geomorphology: the case studies of Pisticci and Corleto Perticara (Basilicata, Italy). DOI:https://doi.org/10.1007/s12371019-00373-2. Geoheritage this volume

Sánchez RM, Rodríguez RC, Sánchez Martín JM (2019) Geotourist profile identification using binary logit modelling: application to the villuercas-ibores-jara geopark (Spain). Geoheritage this volume

Sardella R, Iurino DA, Mecozzi B, Sigari D, Bona F, Bellucci L, Coltorti M, Conti J, Lembo G, Muttillo B, Mazzini I (2019) Grotta Romanelli (Lecce, Southern Italy) between past and future: new studies and perspectives for an archaeo-geosite symbol of the Palaeolithic in Europe. Geoheritage this volume

Shekhar S, Kumar P, Chauhan G, Thakkar MG (2019) Conservation and sustainable development of geoheritage. A case study of Cenozoic Successions of Western Kutch, India. Geoheritage this volume, Geopark and Geotourism

Tognaccini S. (2019) The proposed geosite of volano landslide and a geomorphological itinerary within the Valdelsa basin (Montespertoli, Tuscany, Italy). Geoheritage this volume

Yaseen M, Ghani M, Anjum N, Sajid M, Ullah Jan I, Mehmood M, Ullah Waqas Muzaffir E (2019) A novel approach to evaluate, highlight, and conserve the geologically significant geoheritage sites from the Peshawar basin Khyber Pakhtunkhwa, Pakistan: insights into their geoscientific, educational and social importance. Geoheritage this volume 